\title{
PERFORMANCE ANALYSIS OF RCC AND STEEL CONCRETE COMPOSITE STRUCTURE UNDER SEISMIC EFFECT
}

\author{
Abhishek Sanjay Mahajan", Laxman G. Kalurkar ${ }^{2}$ \\ ${ }^{1}$ M.E.Student in Structural Engineering, Civil Engineering Department, J.N.E.C. Aurangabad, Maharashtra, India \\ ${ }^{2}$ Professor, Civil Engineering Department, J.N.E.C. Aurangabad, Maharashtra, India
}

\begin{abstract}
The RCC Structure is no longer suitable because of increased dead load, span rejection and less stiffness .The structural engineers are trying to use different materials for most efficient design solution.There is great potential for increasing volume of steel in construction. The percentage of steel can be increased with the use of steel-concrete composite sections. The paper presents the effect of FEC (Fully Encased Composite) on a G+ 20 storey special moment frame. In this paper two different structures are considered for the comparison under seismic analysis. The linear static analysis and nonlinear static analysis i.e. "Pushover analysis" are done for G+20 storey structure. The building is analyzed and design for seismic loading by using ETAB software. The unique method of pushover analysis is followed with the help of FEMA 36 specifications and for hinge formation ATC40 is considered. Results are compared for the Base shear, Modal time period, Storey displacement and storey drift for both structures. As the composite is having more lateral stiffness, the results of time period and storey displacement shows the significant variation. While analyzing for "Non-linear static analysis the performance point for the FEC is significantly much more as compared to the RCC model.
\end{abstract}

Keywords: Composite, RCC Structure, Static Linear, Non Linear Static

\section{INTRODUCTION}

Structural engineers are facing challenges in fulfilling the demand of effective and economical design solution for high rise structures. In India reinforced cement concrete members are mostly used as a structural member and they seems to be the best design solution for low rise building structure. But in case of high rise structure RCC members are no longer suitable because of their increased dead load, limitation of span length and less stiffness. To overcome such defects structural engineers are using different materials to their best utilization. There is a great potential for increasing volume of steel in construction, steel can be used as an alternative construction material. The composite section using steel encased with concrete is effective solution in major civil structures.

This paper presents the study of effect of FEC (Fully Encased Composite) on ( $\mathrm{G}+20)$ storey building structure. ETAB software is used for analyzing the structure under seismic effect. For seismic analysis the non-linear static analysis i.e. Pushover Analysis and linear static analysis are done .Results are compared for Base Shear, Modal Time Period, Storey Displacement and Storey Drift.

\subsection{Composite Structure}

Composite structure can be defined as the structures in which composite sections made up of two different types of materials such as steel and concrete are used for beams and columns. Composite construction combines the better properties in both, concrete in compression and steel in tension, they have almost the same thermal expansion and results in speedy construction. Two different materials are tied together by the use of shear studs at their interface having lesser depth in composite construction. Structural components use in composite construction consists of the following elements.

- Composite slab

- Composite beam

- Composite column

- Shear connector

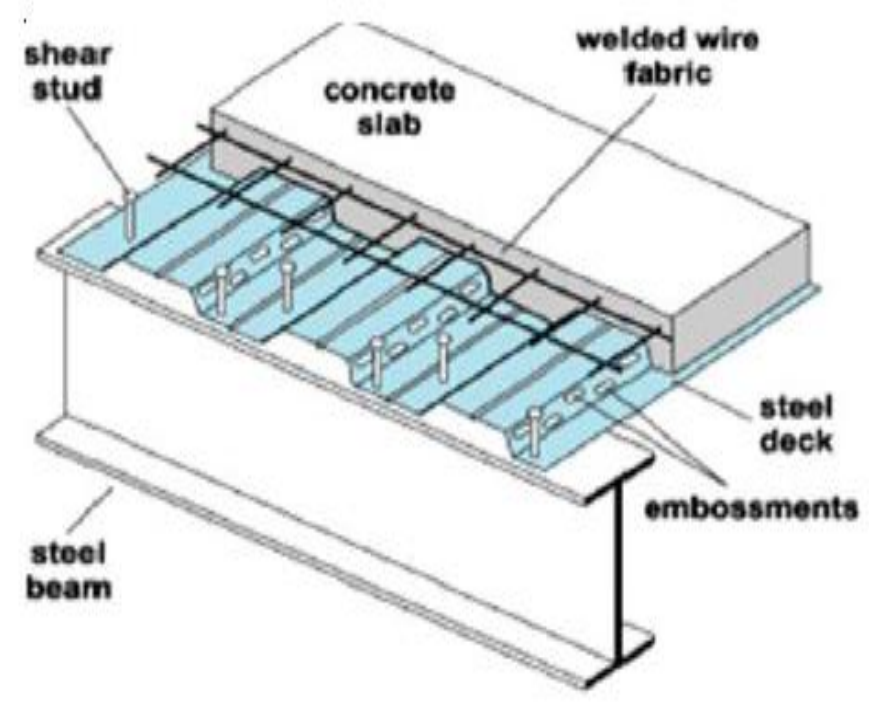

Fig -1: Typical Composite Section Arrangement 


\subsection{Why Composite}

The advantages of steel concrete composite construction may be emulated as

A. Considerably flexible in design and ease of fabrication.

B. Ideal material in earthquake prone locations due to high strength, stiffness and ductility.

C. The size of the members can be made smaller thus increasing strength to weight ratios.

D. Facilitates faster construction of projects.

E. Satisfies requirement of long span construction, a modern trend in architectural design.

F. Permits easy structural repair and modification.

G. Properly designed composite steel and concrete members prevent the brittle failure mode of reinforced concrete members and have significant ductility.

H. The encased steel frame can be used as shoring system for concrete forms during construction

\section{OBJECTIVE OF STUDY}

- To check whether the steel encased concrete composite sections are best economic and time effective solution for high rise structure..

- To study behavior of steel concrete composite structure under seismic loading.
- To check whether the steel-concrete composite (FEC) sections are the best alternative to RCC sections used in high rise building.

To satisfy these three objectives the comparative study has been carried out on a G+20 storey structure and comparison is done on the results of Base Shear, Storey Displacement, Time Period and Performance Point for Spectral Displacement. To satisfy the second objective the seismic analysis is done by linear static method and non-linear static method i.e. Pushover analysis.

\section{DESIGN CONSIDERATIONS}

To complete this study a G+20 storey residential building is considered for analysis. As the normal structure will not require a composite section's study purpose high rise structure is selected. A symmetric plan is selected and the plan dimensions are $30 \mathrm{~m} \mathrm{X} 12 \mathrm{~m}$. The building is located in Mumbai region in Earthquake zone III and having zone factor equal to 0.24 . Wind velocity is $44 \mathrm{~m} / \mathrm{sec}$.

In preliminary attempt of an analysis the RCC structure is analyzed and designed accordingly to finalize the column sizes, subsequently the sections are finalized for composite structure. Static loading is considered as per IS-875 Part II, For assigning the earthquake parameters Mumbai region is selected.

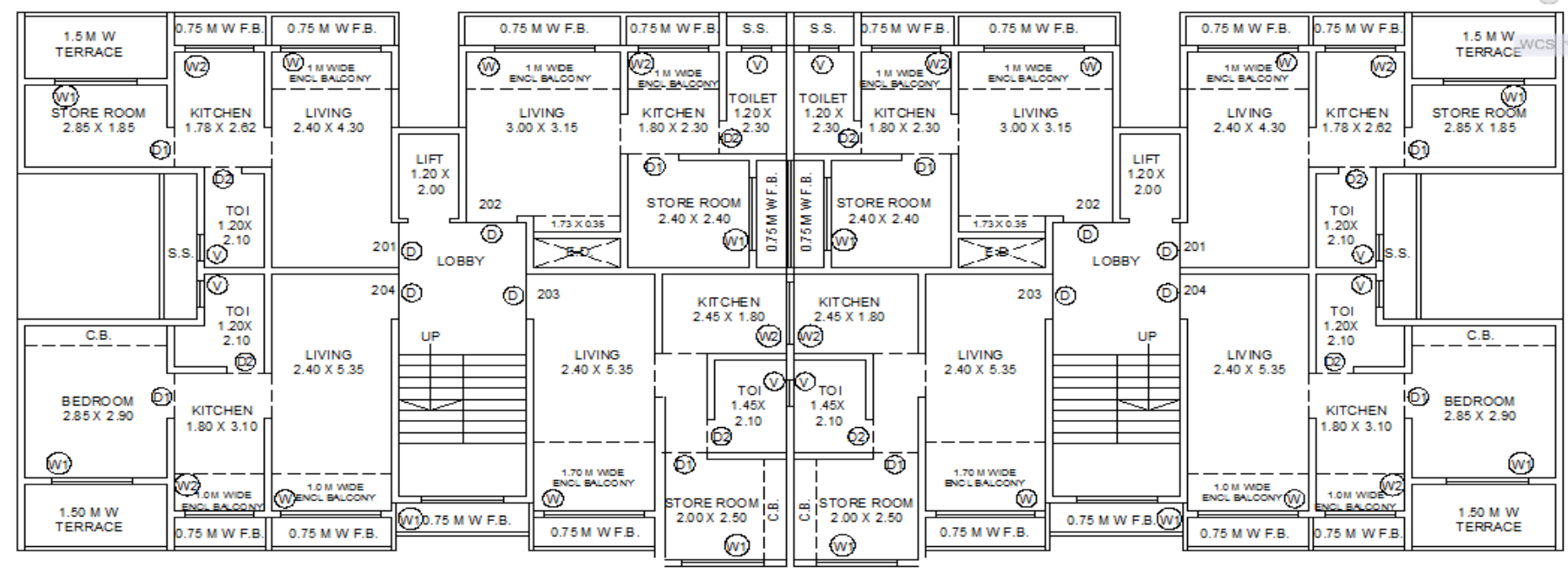

Fig -2: Architectural Plan

Table -1: Project Details

\begin{tabular}{|l|l|}
\hline Plan Dimension & $30 \mathrm{~m} \mathrm{X} \mathrm{12m}$ \\
\hline Total Height of Building & $62.9 \mathrm{~m}$ \\
\hline Height of Each storey & $3 \mathrm{~m}$ \\
\hline Height of Parapet & $1 \mathrm{~m}$ \\
\hline Depth of Foundation & $2.9 \mathrm{~m}$ \\
\hline Size Of Beam & $230 \mathrm{~mm} \mathrm{X} \mathrm{450} \mathrm{mm}$ \\
\hline Size Of Column & $230 \mathrm{~mm} \mathrm{X} 600 \mathrm{~mm}$ \\
\hline Thickness of Slab & $200 \mathrm{~mm}, 125 \mathrm{~mm}$ \\
\hline Thickness of Wall & $150 \mathrm{~mm}$ \\
\hline Seismic zone & III \\
\hline
\end{tabular}

\begin{tabular}{|l|l|}
\hline Zone Factor & 0.16 \\
\hline Soil Condition & Hard soil \\
\hline Importance factor & 1.0 \\
\hline Wind speed & $44 \mathrm{~m} / \mathrm{sec}^{2}$ \\
\hline Floor Finish & $1 \mathrm{KN} / \mathrm{m}^{2}$ \\
\hline Live Load & $2 \mathrm{KN} / \mathrm{m}^{2}$ \\
\hline Grade Of Concrete & $20 \mathrm{~N} / \mathrm{mm}^{2}$ \\
\hline Grade Of Steel & $500 \mathrm{~N} / \mathrm{mm}^{2}$ \\
\hline UDL on beam & $7.65 \mathrm{KN} / \mathrm{m}^{2}$ \\
\hline Density Of Brick & $20 \mathrm{KN} / \mathrm{mm}^{3}$ \\
\hline
\end{tabular}


As study primarily focuses on the seismic assessment and comparison between the RCC and composite structure both structures are analyzed for nonlinear static analysis i.e. pushover method. Nonlinear hinges are assigned to the structure. Analysis is performed in the finite element oriented software i.e. ETABS version 2015. Pushover analysis is performed with the help of FEMA and ATC 40 code. The initial displacement has out and same is used as initial displacement for pushover analysis.

\section{RESULTS AND CONCLUSION}

Results are obtained for both structures i.e. RCC and Composite (FEC). For linear static analysis load values are taken as per IS 1893 part II. Results obtained are :

\section{A. Base Shear}

As the base shear is the horizontal reaction to the earthquake forces and horizontal forces results from the storey weight. Storey weight includes the self-weight of the structure also; hence in the reinforced cement concrete model the selfweight is seems to be the more and hence maximizing the earthquake forces which results in the maximum base shear. As we have the static formula for base shear As base shear is the direct function of the seismic weight therefore naturally base shear is more in the case of RCC structure. The graph clearly shows that the Base Shear of RCC is more than Composite .

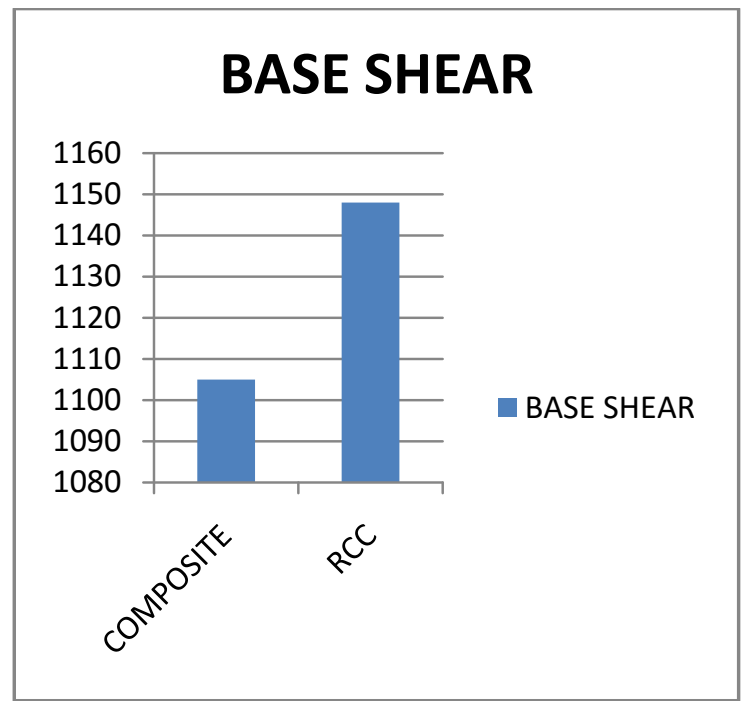

Chart -1: Base Shear

\section{B. Time period}

In any structure the stresses are basically calculated from the net displacement of each and every node in various directions. Once we calculated the displacements then we can work out the strains and hence we can work out the stresses by flexural equation. i.e. $\mathrm{E} / \mathrm{R}=\mathrm{M} / \mathrm{I}=\mathrm{F} / \mathrm{Y}$. now taking account the time period, it is the time required to complete the single oscillation, if time period is more naturally the displacement will be more and as discussed above stresses will be more. So time period is itself pasteurizes the stresses. As in above graph time period for RCC structure is more as compared to the composite structure. This is primarily because of having more lateral stiffness for composite structure as it is having I - sections embedded in the concrete.

\section{Storey Height against Storey Displacement}

As structure is having maximum height naturally it will experiences the maximum displacement at top, so in both structures (RCC and COMPOSITE) the storey displacement of both structures has been carried out and compared the variation in the maximum top node displacement is seem to be $22 \%$ whereas the displacement for $19^{\text {th }}$ storey is seemed to be $21 \%$ and it is much significant and considerable.

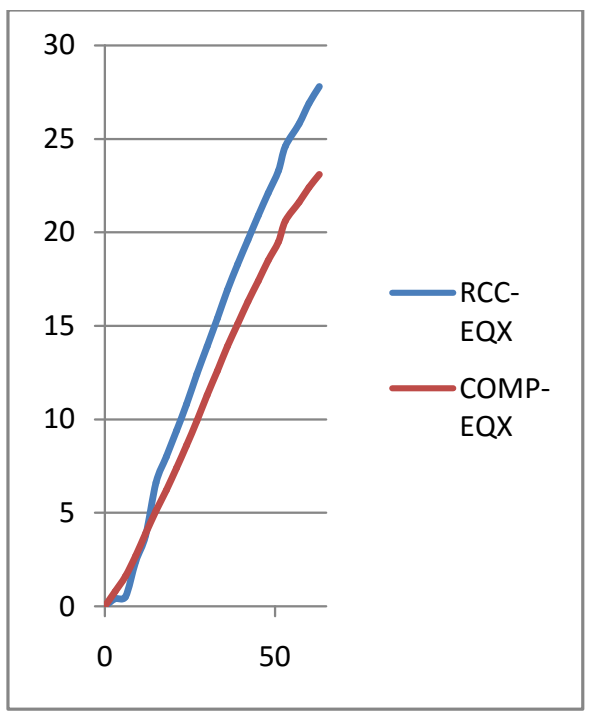

Chart -2: Storey Height Against Storey Displacement In X Direction

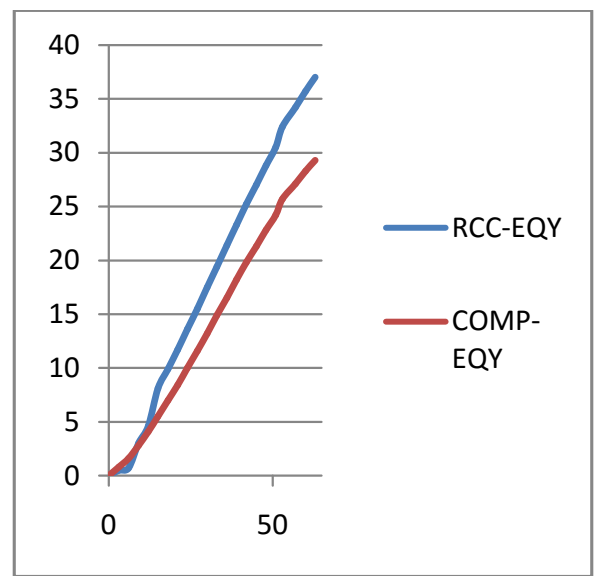

Chart -3: Storey Height Against Storey Displacement In Y Direction

\subsection{Performance Point}

The performance point of the structure is the point where demand spectrum and capacity of the structure intersects each other. Performance point decides the flexibility or stiffness of the structure. As we can observe in the graph performance point for the FES model is much more than the RCC model. There is significant variation of $21 \%$ in the performance point. 


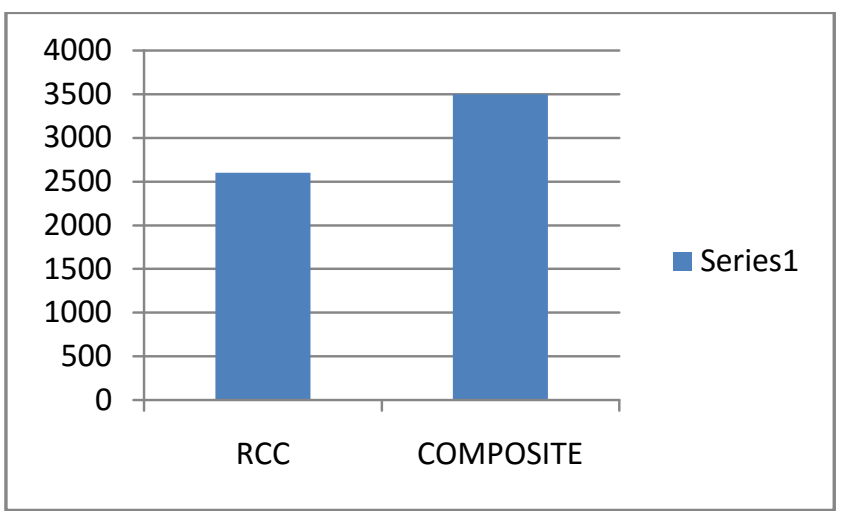

Chart -4 Performance Point For Spectral Displacement

Performance point of spectral velocity is also compared and having significant variation in both Structures .The criteria's for safety level against the earthquake is defined in four category i.e. Immediate occupancy, Life safety, Basic, and Collapse prevention, the degree of safety in any structure when given the unit displacement it experiences the lateral moment and deflection. As we can observe in the graph the safety level for the graph FEC structure is having slightly much more stiffness which results in minimum lateral displacements.

\subsection{Assessment For Biaxial Moment}

For calculating the performance point the angle of approach for the analysis is kept zero degree but in the further study the angle of approach is change to different directions and results are worked out. Subsequently the structure is analyzed for 0, 45 and 90 degree angle. If angle of approach is zero degree then column experiences only uniaxial moment, but when analyzed for 45 and degree it experience the biaxial moment which affects the location of plastic hinge formation in the structure. The significant variation of $13 \%$ is seen in the corner column between zero degree and 45 degree angle of approach.

\section{ACKNOWLEDGEMENT}

This paper too could not be completed without the help and support of many special person.

\section{REFERENCES}

[1]. Baldev D. Prajapati \& D. R. Panchal 'STUDY OF SEISMIC AND WIND EFFECTON MULTI STOREY R.C.C., STEEL AND COMPOSITE BUILDING', International Journal of Advances in Engineering \& Technology, Sept. 2013

[2]. Prof. S. S. Charantimath , Prof. Swapnil B.Cholekar, Manjunath M. Birje" Comparative Study on Structural Parameter of R.C.C and Composite Building" Civil and Environmental Research ISSN 2224-5790 (Paper) ISSN 2225-0514 (Online) Vol.6, No.6, 2014

[3]. Zafar Mujawar, Prakarsh Sangave 'Comparative Evaluation Of Reinforced Concrete, Steel And Composite Structures Under The Effect Of Static And Dynamic Loads" Int. Journal of Engineering Research and
Applications ,ISSN : 2248-9622, Vol. 5, Issue 1( Part 5), January 2015, pp.41-44

[4] BY;- Anish N. Shah, Dr. P.S. Pajgade 'CComparison Of R.C.C. And Composite Multistoried Buildings", International Journal of Engineering Research and Applications (IJERA) ISSN: 2248-9622,Vol. 3, Issue 2, March -April 2013, pp.534-539

[5] Shweta A. Wagh ,Prof. Dr. U. P. Waghe " Comparative Study of R.C.C and Steel Concrete Composite Structures" Int. Journal of Engineering Research and Applications ,ISSN : 2248-9622, Vol. 4, Issue 4( Version 1), April 2014

[6] IS 11384 "Code of practice for composite construction in structural steel and concrete, Bureau of Indian Standards", NewDelhi, 1985.

[7] IS: 456, Code of practice for plain and reinforced concrete code of practice, Bureau of Indian Standards, New Delhi, 2000

[8] IS: 1893, Criteria for earthquake resistant design of structures - general provisions for buildings, Part 1, Bureau of Indian Standards, New Delhi, 2002

[10] Mahesh Suresh Kumawat and L G Kalurkar ' COST ANALYSIS OF STEEL-CONCRETE COMPOSITE STRUCTURE', ISSN 2319 - 6009,Vol. 3, No. 2, May 2014 , IJSCER

[11] C. C. Weng, S. I. Yen, and C. C. Chen "'SHEAR STRENGTH OF CONCRETE-ENCASED COMPOSITE STRUCTURAL MEMBERS" Journal Of Structural Engineering / October 2001

[12] Ketan Patela, Sonal Thakkar " ANALYSIS OF CFT, RCC AND STEEL BUILDING SUBJECTED TO LATERAL LOADING', Science Direct Procedia Engineering 51 ( 2013 ) 259 - 265 